\title{
PENGARUH MEDIA PEMBELAJARAN DAN GAYA BELAJAR TERHADAP HASIL BELAJAR BIOLOGI
}

\author{
Rena Agustina ${ }^{1}$ dan Harun Sitompul ${ }^{2}$ \\ SMA Swasta Persiapan Stabat ${ }^{1}$ dan Universitas Negeri Medan ${ }^{2}$ \\ renaagustina@yahoo.com ${ }^{l}$ dan prof_runsit@yahoo.co.id ${ }^{2}$
}

\begin{abstract}
Abstrak: Penelitian ini bertujuan untuk mengetahui: (1) siswa yang diajar dengan media pembelajaran animasi hasil belajarnya lebih tinggi dari media pembelajaran powerpoint. (2) hasil belajar siswa yang memiliki gaya belajar visual hasil belajar lebih tinggi dari gaya belajar auditori (3) ada interaksi antara media pembelajaran dengan gaya belajar, dalam mempengaruhi hasil belajar biologi siswa. Metode penelitian kuasi eksperimen dengan desain faktorial $2 \times 2$ dan cluster random sampling. Statistik deskriptif untuk menyajikan data dab statistik inferensial digunakan ANAVA 2 jalur. Sebelum ANAVA 2 jalur digunakan terlebih dahulu dilakukan uji persyaratan analisis data yaitu uji normalitas dengan uji Liliefors dan uji homogenitas varians dengan uji Barlett pada taraf signifikansi 0.05. Hasil penelitian: (1) hasil belajar Biologi siswa yang diajar dengan media pembelajaran Animasi lebih tinggi dibandingkan media pembelajaran Powerpoint Besarnya $F_{\text {hitung }}=19.042>F_{\text {tabel }}=3.98$; (2) siswa yang memiliki Gaya Belajar Visual lebih tinggi dibandingkan Gaya Belajar auditori i. Besarnya $F_{\text {hitung }}=47.884>F_{\text {tabel }}=3.98$; (3) Terdapat interaksi antara media pembelajaran dan gaya belajar dalam mempengaruhi hasil belajar kewirausahaan siswa SMA Swasta persiapan stabat. Besarnya $F_{\text {hitung }}=44.039>F_{\text {tabel }}=$ 3.98
\end{abstract}

Kata Kunci: media pembelajaran, gaya belajar, hasil belajar biologi

Abstract: This study aims to determine: (1) students who are taught with an animated instructional media learning outcomes are higher than PowerPoint instructional media. (2) the learning outcomes of students who have a visual learning style learning outcomes are higher than auditory learning style (3) there is an interaction between the media with learning styles, to influence biology student learning outcomes. Quasi-experimental research method with a $2 \times 2$ factorial design and cluster random sampling. Descriptive statistics to present data dab inferential statistics used ANOVA 2 lanes. Before ANOVA 2 lanes used first tested the data analysis requirements that normality test with Liliefors test and test homogeneity of variance with Bartlett's test at the 0.05 significance level. Results of the study: (1) the results of studying biology students taught by instructional media animations higher than a medium of learning Powerpoint amount of $F \mathrm{C}=19$ $042>F t=3.98$; (2) students who have a Learning Styles Visual higher than auditory learning styles $i$. The magnitude of $F c=47884>F t=3.98$; (3) There is interaction between media teaching and learning styles in affecting learning outcomes entrepreneurial private high school students Stabat preparation. The magnitude of $F c=44039>F t=3.98$

Keywords: learning media, learning styles, learning outcomes biology

\section{PENDAHULUAN}

Rendahnya perolehan belajar siswa dalam kegiatan belajar megajar sehari-hari khususnya dalam mata pelajaran biologi, merupakan hal yang perlu dicermati. Laporan penelitian yang dilakukan Ibrahim (1996) menyatakan secara kualitatif kondisi pendidikan di Indonesia bermasalah, salah satu masalah adalah rata-rata nilai ujian akhir nasional (UAN) yang masih tergolong rendah. Rendahnya hasil belajar siswa yang digambarkan oleh nilai akhir UAN ini juga terjadi di SMA Swasta Persiapan Stabat. Berdasarkan data yang diperoleh, nilai rata-rata Ujian Nasional semua mata pelajaran yang di UAN kan jika pada tahun terakhir menunjukkan hasil yang belum menggembirakan dan masih jauh dari standar nilai ketuntasan belajar yang diharapkan.

Terlalu padatnya target materi pembelajaran yang harus dicapai dari mata pelajaran Biologi, sehingga sulit untuk 
mengembangkan aspek keterampilan proses dalam kegiatan belajar mengajar. Sebagian besar guru baru mampu untuk berupaya mencapai target kurikulum dalam arti menyelesaikan materi pembelajaran, mengevaluasi produk melalui tes formatif dan sumatif, hal ini ditambah dengan pendapat siswa bahwa pelajaran Biologi dianggap sulit, memiliki banyak hapalan dan bahasa latin sehingga tidak menarik untuk belajar sehingga berdampak pada rendahnya hasil belajar yang diperoleh siswa. Masalah lain yang ditemukan peneliti adalah kurangnya perhatian guru dalam mengaktifkan siswa dalam kegiatan belajar mengajar, serta dalam menjelaskan materi Biologi guru cenderung menggunakan metode ceramah.

Dari hasil observasi ditemukan bahwa ada kesenjangan yang terjadi di lapangan yang membuat proses pembelajaran di dalam kelas tidak berlangsung dengan efektif dan efesien. Untuk mengatasi kesenjangan tersebut perlu diidentifikasi faktor permasalahan yang menjadi penyebab kesenjanagan itu terjadi.

Dengan kata lain, prinsip kerjasama dalam kelompok kurang diperhatikan. Jika dilakukan kerjasama kelompok umumnya yang terjadi adalah siswa yang berprestasi lebih tinggi yang dominan untuk menguasai materi yang diberikan, sedangkan siswa yang berprestasi rendah kurang aktif dan terkesan hanya sebagai penonton saja selama kerjasama dalam kelompok dilakukan. Padahal agar kelas menjadi lebih produktif, dalam pembelajaran sangat diperlukan kerjasama antara sesama anggota kelompok yang memiliki latar belakang pengetahuan yang berbeda dalam memecahkan berbagai permasalahan.

Menurut Ali (2005), faktor utama penyebab pembelajaran di dalam kelas tidak efektif adalah penggunaan media dan strategi pembelajaran yang tidak tepat. Pembuatan media pembelajaran yang tepat menurut Sardiman (1993) akan dapat mengatasi masalah sikap pasif siswa yang pada akhirnya menimbulkan kegairahan dalam belajar dan memungkinkan siswa untuk belajar sendiri. Beragam proses dan aspek pengetahuan ssiwa dalam kelas dapat dikembangkan guru dengan cara menawarkan media dan strategi pembelajaran yang berbeda-beda.

Pemilihan strategi pembelajaran yang tepat merupakan tuntutan yang harus dipenuhi oleh seorang peserta didik. Di dalam proses belajar mengajar, guru harus memiliki strategi, agar siswa dapat belajar secara efektif dan efesien, mengena pada tujuan yang diharapkan (Roestiyah, 2008:41). Strategi pembealjaran ini berkaitan dengan keberhasilan proses belajar mengajar yang hasilnya akan menentukan prestasi yang akan dicapai oleh siswa. Menurut Sanjaya (2008 : 78) strategi disusun untuk mencapai tujuan tertentu, artinya penyusunan langkah-langkah pembelajaran, pemanfaatan berbagai fasilitas dan sumber belajar semuanya diarahkan dalam upaya pencapaian tujuan. Lebih lanjut Sanjaya (2009) mengemukakan, bahwa masih banyak guru di Indonesia yang menggunakan strategi pembelajaran yang sama untuk semua pokok bahasan, selain itu kebanyakan guru di Indonesia menggunakan strategi pem,belajaran yang berorientasi kemauannya sendiri. Hal ini berarti bahwa masih banyak di Indonesia tidak dapat memilih strategi pemebalajran yang tepat untuk satu pokok mata pelajaran tertentu sehingga menyebabkan rendahnya hasil belajar siswa.

Nurhadi (2005) mengatakan bahwa kebanyakan guru di Indonesia masih cenderung menggunakan strategi pemebaljaran ekspositori yakni strategi pembelajaran yang beorienasti pada guru. Masih banyak guru beranggapan bahwa strategi ekspositori lebih baik dari dari strategi yang lain.

Hal serupa juga ditemukan di SMA Swasta Persiapan Stabat. Berdasarkan identifikasi masalah yang dilakukan pada observasi awal pada guru-guru SMA Swasta Persiapan Stabat khususnya pada guru-guru mata pelajaran biologi menunjukkan bahwa guru-guru mata pelajaran biologi di SMA Swasta persiapan Stabat masih cenderung menggunakan strategi pembelajaran yang berorientasi pada guru (teacher centered). Padahal Gropper (1990) mengatakan bahwa strategi pembelajaran yang baik merupakan pemilihan atas berbagai jenis latihan tertentu yang sesuai dengan tujuan pembelajaran yang ingin dicapai. Hal ini menunjukkan, bahwa masih banyak guru di Indonesia menggunakan strategi pembelajaran bukan melalui pemilihan atau latihan dan tidak memikirkan kefektifan strategi pembelajaran yang digunakan untuk mencapi tujuan instruksional secara maksimal.

Begitu juga dengan penggunaan media, melalui identifikasi masalah yang dilakukan pada observasi awal terhadap guru-guru khususnya guru-guru mata pelajaran Biologi di SMA Swasta Pesiapan Stabat menunjukkan bahwa hampir 60\% guru Biologi SMA Swasta 
Persiapan Stabat tidak menggunakan media saat proses pembelajaran berlangsung. Penggunaan media yang tepat menurut Sardiman (1993) akan dapat mengatasi masalah sikap pasif siswa, yang apda akhirnya menimbulkan kegairahan dalam belajar dan memungkinkan anak untuk belajar sendiri. Sanjaya (2009) mengatakan bahwa media sangat dibutuhkan saat mengajarkan materi yang tergolong abstrak dan sulit diajarkan, karena media dapat membuat pengetahuan yang abstrak menjadi lebih konkret. Pengetahuan siswa seperti yang digambarkan oleh Edgar Dale ( dalam Sanjaya, 2009) yang dikenal dengan Kerucut Pengalaman Edgar Dale.

Pemilihan media ini didasari oleh berbagai penelitian tentang media Animasi dan media gambar, antara lain : Talib (2005) menerangkan hasil-hasil penelitian tentang keunggulan penggunaan animasi komputer, antara lain : animasi komputer dapat meningkatkan penemuan lingkungan, dapat merubah pandangan alternative siswa, mendukung kolaborasi belajar, menciptakan proses teknologi, meningkatkan pemahaman konsep ilmiah, meningkatkan motivasi belajar, meningkatkan hasil belajar, dan menstimulasi kemampuan memecahkan masalah secara ilmiah. Hasil-hasil dapat menegaskan, bahwa penggunaan animasi komputer pada pembelajaran sangat potensial untu merangsang siswa untuk mencapai tujuan belajar mereka. Ari Dalton (2006) menjelaskan, bahwa animasi komputer dapat meningkatkan hasil belajar mahasiswa secara signifikan daripadayang hanya diperlihatkan dengan teks dalam waktu yang sama. Lebih lanjut dikatakan bahwa animasi dapat meningkatkan penyimpanan memori jangka penjang yang lebih baik bagi siswa dibandingkan dengan gambar sederhana. Menurut Nichollas dan Merkel (1996) animasi lebih efektif daripada urutan gambar diam dalam proses pembelajaran.

Menurut Surya dalam Rusman (2012 : 85 ) belajar dapat diartikan sebagai suatu proses yang dilakukan oleh individu untuk memperoleh perubahan perilaku baru secara keseluruhan, sebagai hasil dari pengalaman individu itu sendiri dalam berinteraksi dengan lingkungannya. Menurut Dimyati dan Mudjiono dalam Sagala ( 2005 :13 ) mengemukakan siswa adalah penentu terjadinya atau tidak terjadinya proses belajar. Corbanch dalam Rusman (2012 : 86) berpendapat bahwa learning is shown by change in behavior as a result of experience. Belajar sebagai suatu aktivitas yang ditunjukkan oleh perubahan tingkah laku sebagai hasil pengalaman. Makna dari defenisi yang dikemukakan oleh Corbanch lebih dalam lagi, bahwa belajar bukanlah semata-mata perubahan dan penemuan, tetapi sudah mencakup kecakapan yang dihasilkan akibat perubahan dan penemuan tadi. Setelah terjadi perubahan dan menemukan sesuatu yang baru, maka akan timbul suatu kecakapan yang memberikan manfaat bagi kehidupannya. Intinya belajar adalah out come.

Senada dengan itu, teori behavioristik menyatakan bahwa belajar adalah perubahan tingkah laku sebagai akibat dari adanya interaksi antara stimulus dan respon. Dengan kata lain belajar merupakan bentuk perubahan yang dialami oleh siswa dalam hal kemampuan untuk bertingkah lakudengan cara yang baru sebagai hasil interaksi antara stimulus dan respon (dalam Asri, 2005).

Dari beberapa pengertian belajar di atas, kata kunci dari belajar adalah perubahan perilaku siswa baik seacara psikologi maupun fisiologi, disadari dan disengaja yang tejadi secara berkesinambungan yang pada akhirnya perubahan tersebut akan bersifat positif.

Sedangkan Romiszowski mengatakan bahwa hasil belajar ditunjukkan dalam bentuk penegtahuan dan keterampilan. Pengetahuan dikelompokkan dalam empat kategori, yaitu fakta, konsep, prosedur, dan prinsip. Fakta merupakan pengetahuan tentang objek nyata, asosiasi, kenyataan dan informasi verbal dari suatu objek. Konsep adalah pengetahuan tentang seperangkat objek konkrit atau defenisi. Prosedur merupakan pengetahuan tentang tindakan yang bersifat linier dalam mencapai tujuan. Selanjutnya prinsip adalah pernyataan mengenai hubungan dari dua konsep atau lebih.

Reigeluth (1979) mengemukakan bahwa hasil belajar merupakan salah satu aspek pengajaran yang dibagi menjadi tiga jenis yaitu : (1) keefektifan pengajaran yang diukur dengan tingkat pencapaian si belajar pada tujuan atau isi bidang studi yang telah ditetapkan, (2) efesiensi pengajaran diukur dengan rasio antara keefektifan dan jumlah waktu yang dipakai si belajar dan atau jumlah biaya pengajaran yang digunakan, dan (3) daya tarik pengajaran yang diukur dengan mengamati kecendrungan siswa untuk tetap belajar (dalam Degeng, 1989).

Sementara Joice dan Well (1980 : 1986) mengacukan hasil belajar atau pengajaran 
langsung instrukctional effects, dan pengajaran yang terbentuk secara kumulatif disebutnya sebagai nurturant effects. Hasil belajar diukur setelah siswa mengikuti semua kegiatan pembelajaran dengan tes hasil belajar.

Merill (1983) mengklasifikasikan hasil belajar menjadi dua dimensi: tingkat unjuk kerja dan tipe isi. Klasifikasi ini hanya diterapkan dalam belajar ranah kognitif. Dimensi tingkat unjuk kerja dibagi menjadi tiga yaitu : (1) mengingat, (2) menggunakan, (3) menemukan. Sedangkan tipe isi pengajaran dibedakan menjadi empat yaitu : (1) fakta, (2) konsep, (3) prosedur, (4) prinsip, ( dalam Degeng (1986)).

Menurut Romiszowski (1981), setiap strategi pembelajaran yang dikembangkan selalu mencerminkan posisi teoritis yang dianut tentang bagaimana seharusnya pembelajaran itu dilaksanakan. Senada dengan pendapat tersebut, Hamalik (1993) mendefenisikan bahwa strategi pembelajaran sebagai sistem yang menyeluruh dan terdiri dari komponen masukan (input), pengolahan (Process), dan keluaran / produk (output).

Strategi pembelajaran menurut J.R. David dalam Teacing Strategis for Collage Class Room (1976), aialah a plan, method, or series of activites designed to achieves a particular educational goal . Menurut pengertian ini strategi pembelajaran meliputi rencana, metode dan perangkat kegiatan yang direncanakan untuk mencapai tujuan pengajaran tertentu.

Strategi pembelajaran adalah suatu kegiatan pembelajaran yang harus dikerjakan guru dan siswa agar tujuan pemeblajaran dapat dicapai secara efektif dan efesien (Kemp, 1995 dalam Sanjaya, 2006). Dengan mempersiapkan suatu rencana kegiatan pembelajaran persiapan strategi pembelajaran serta perangkat yang diperlukan dalam pembelajaran, maka supaya untuk mencapai tujuan pembelajaran lebih memungkinkan untuk dicapai. Senada dengan itu, Reigeluth dan Merril (1979) dalam degeng, mengemukakan bahwa pengukuran keefektifan pengajaran harus selalu dikaitkan dengan pencapaian tujuan pengajaran. Dengan kata lain, agar hasil belajar menjdai lebih efektif seorang guru harus membuat sebuah strategi atau perencanaan yang matang untuk mencapai tujuan yang diharapkan, ini berarti sebuah strategi pembelajaran yang didesain dengan baik akan berpengaruh pada hasil yang baik pula.
Efektifitas strategi pembelajaran di kelas dalam mencapai tujuan belajar dapat dilihat dari seberapa tinggi hasil belajar yang dicapai oleh siswa. Dick dan Carey (2005) menjelaskan bahwa strategi pembelajaran menggambarkan komponen-komponen umum dari suatu set bahan pembelajaran yang digunakan untuk menghasilkan belajar tertentu siswa. Dalam strategi pembelajaran terkandung empat komponen, berupa : (1) urutan kegiatan pembelajaran, yaitu urutan kegiatan pengajar dalam menyampaikan isi pelajaran kepada siswa, yang terdiri dari pendahuluan, penyajian dan penutup, (2) metode pembelajaran, yaitu cara pengajar mengorganisasikan materi pelajaran dan siswa agar terjadi proses belajar secara efektif dan efisien, (3) media pembelajaran, yaitu peralatan dan bahan pembelajaran yang digunakan pengajar dan siswa dalam kegiatan pembelajaran, dan (4) waktu yang digunakan oleh pengajar dan siswa dalam menyelesaikan setiap langkah dalam urutan kegiatan pembelajaran.Untuk lebih jelasnya dapat dilihat pada tabel berikut.

Berdasarkan penjelasan di atas, maka dalam penelitian ini yang dimaksud dengan strategi pembelajaran adalah rangkaian kegiatan pembelajaran yang didalamnya memuat aktivitas pendahuluan, penyampaian informasi, partisipasi siswa dan tes yang diadopsi dari langkah-langkah pembelajaran yang dikemukakan oleh Dick dan Carey (2005)

Pembelajaran ekspositori adalah pembelajaran yang menekankan kepada proses penyampaian materi secara verbal dari seorang guru kepada sekelompok siswa dengan maksud agar siswa dapat menguasai materi pelajaran secara optimal (Sanjaya, 2005). Pembelajaran ekspositori umunya berorientasi pada kegiatan yang berpusat pada guru (teacher oriented). Kebanyakan siswa bersifat pasif karena hanya mendengarkan cermah atau kuliah dari guru tentang materi pelajaran yang disampaikan. Strategi pembelajaran ekspositori merupakan kegiatan pembelajaran di mana guru sangat berperan sebagai sumber belajar sekaligus bertindak sebagai penyaji isi pembelajaran.

Menurut Sudjana (1991) ciri-ciri pembelajaran ekspositori adalah pembelajaran berpusat pada guru, siswa mendengar dan mencatat seperlunya, komunikasi terjadi satu arah, menyamaratakan kemampuan siswa dan siswa kurang keberanian dalam bertanya. Pada strategi pembelajaran ekspositori, siswa belajar dengan mendengarkan penjelasan guru di depan 
kelas dan melaksanakan tugas jika guru memberikan latihan soal-soal kepada siswa tersebut. Semua anak dinilai sama tanpa membedakan siswa yang berinteligensi tinggi dengan siswa yang berintilegensi rendah, jadi terkesan bahwa yang kurang pandai dipaksakan untukberjalan cepat seiring dengan temannya yang pandai.

Nurhadi (2003) mengemukakan beberapa ciri pembelajaran ekspositori yaitu : (1) siswa menerima informasi secara pasif, (2) perilaku dibangun atas kebiasaan, (3) keterampilan dikembangkan atas dasar latihan, (4) pengetahuan adalah penangkapan terhadap serangkaian fakta, konsep atau hukum yang berada di luar siswa, (5) dalam proses pembelajaran bersifat absolut dan final, hal ini disebabkan siswa tidak memperhatikan pengalaman belajar apa yang harus dirangkaikan dalam pikirannya. Strategi pembelajaran ekspositori juga memiliki beberapa ciri sebagai berikut : (1) mengajar berpusat pada bahan pelajaran, tujuan utama pembelajaran adalah mengembangkan bakat berpikir siswa, pengajaran berpusat pada usaha untuk menyampaikan pengetahuan, (2) mengajar berpusat pada guru, guru sangat berperan sebagai sumber belajar, sekaligus bertindak sebagai penyaji isi pelajaran, (3) metode yang digunakan umumnya adalah ceramah ataupun bentuk demonstrasi, disamping metode tanya jawab dan pemberian tugas. Jika ditinjau dari tugas guru yang mengajarkan bahan pelajaran berupa fakta-fakta dari kebudayaan manusia, maka pada strategi pembelajaran ekspositori, siswa akan berusaha menerapkan semua ilmu pengetahuan dengan menghafal. Dan rancangan pembelajaran yang cocok digunakan pada strategi ini dapat dilihat pada tabel berikut.

Menurut Heinich dalam Rusman (2012 : 159) media merupakan alat saluran komunikasi. Media berasal dari bahasa latin dan merupakan bentuk jamak dari kata "medium" yang secara harfiahnya berarti " perantara" yaitu perantara sumber pesan (source) dengan penerima pesan (a receiver). Heinich mencontohkan media ini seperti film, televisi, diagram, bahan tercetak, komputer, dan instruktur. Contoh media tersebut bisa dipertimbangkan sebagai media pembelajaran jika membawa pesan-pesan (messages) dalam rangka mencapai tujuan pembelajaran. Dalam hal ini ada hubungan antara media dengan pesan dan metode.
Media adalah pengantar pesan dari pengirim ke penerima pesan, dengan demikian media pembelajaran merupakan wahana penyalur informasi belajar atau penyalur pesan. National Education association (NEA) atau Asosiasi Teknologi dan Komunikasi Pendidikan Amerika (Sadiman dkk, 2002 : 6) mendefinisikan media sebagai segala bentuk dan saluran yang digunakan orang untuk menyalurkan pesan/informasi.

Media salah satu alat komunikasi dalam menyampaikan pesan tentunya sangat bermanfaat jika diimplementasikan ke dalam proses pembelajaran, media yang digunakan dalam proses pembelajaran tersebut disebut media pembelajaran. Media pembelajaran ini salah satu komponen proses belajar mengajar yang memiliki peranan sangat penting dalam menunjang keberhasilan proses belajar mengajar hal tersebut dengan pendapat Gagne (Rusman, 2012 : 160) menyatakan bahwa 'media adalah berbagaiu jenis komponen dalam lingkungan siswa yang memberikan rangsangan untuk belajar'. Seperti yang telah dikemukakan Gagne, penggunaan media pembelajaran juga dapat memberi rangsangan bagi siswa untuk terjadinya proses belajar dikuatkan oleh pendapat Miarso (2004 : 458) bahwa :" Media pembelajaran adalah segala sesuatu yang digunakan untuk menyalurkan pesan serta dapat merangsang pikiran, perasaan, perhatian, dan kemauan si belajar sehingga dapat medorong terjadinya proses belajar yang disengaja, bertujuan, dan terkendali”.

Media pembelajaran memiliki fungsi yang sangat strategis dalam pembelajaran. Seringkali terjadi banyaknya siswa yang tidak atau kurang memamahi materi pelajaran yang diisampaikan guru atau pembentukan kompetensi yang diberikan pada siswa dikarenakan keadaan atau kurang optimalnya pemberdayaan media pembelajaran dalam proses belajar mengajar. Menurut Rusman (2012:162) Ada beberapa fungsi media pembelajaran dalam pembelajaran di antaranya

a. Sebagai alat bantu dalam proses pembelajaran. Media pembelajaran merupakan alat bentu yang dapat memperjelas, mempermudah, mempercepat penyampaian pesan atau materi pelajaran kepada para siswa sehingga inti materi pelajaran secara utuh dapat disampaikan pada para siswa. Di samping itu, melalaui alat bantu belaajar ini memungkinkan siswa 
belajar secara mandiri sesuai dengan bakat dan kemampuan visual, auditori dan kinestetiknya. Dampak pada siswa lain dalam kelas diharapkan dapat memberikan stimulus, mempersamakan pengalaman dan pemahaman objek pesan yang dismapaikan dalam pembelajaran.

b. Sebagai komponen dari sub sistem pembelajaran. Pembelajaran merupakan suatu sistem yang mana di dalamnya memiliki sub-sub komponen di antaranya adalah komponen media pembelajaran. Dengan demikian media pembelajaran merupakan sub komponen yang dapat menentukan keberhasilan proses maupun hasil pembelajaran.

c. Sebagai pengarah dalam pembelajaran. salah satu fungsi dari media pembelajaran adalah sebagai pengarah pesan atau materi apa yang akan disampaikan, atau kompetensi apa yang akan dikembangkan untuk dimiliki siswa. Banyaknya pembelajaran tidak mencapai hasil prestasi belajar siswa dengan baik karena tidak memiliki atau tidak optimalmya alat bantu yang digunakan dalam pembelajaran.

d. Sebagai permainan atau membangkitkan perhatian dan motivasi siswa. Media pembelajaran dapat membangkitkan perhatian dan motivasi siswa dalam belajar, karena media pembelajaran dapat mengakomodasikan semua kecakapan siswa dalam belajar. Media pembelajaran dapat memberikan bantuan pemahaman pada siswa yang kurang memiliki kecakapan mendengar atau melihat atau kurang memiliki konsentrasi dalam belajar. Dapat pula alat bantu pembelajaran ini menimbulkan gairah belajar, interaksi lebih langsung antara murid dan dengan sumber belajar.

e. Meningkatkan hasil dan proses belajar. Secara kualitas dan kuantitas media pembelajaran sangat memberikan konstribusi terhadap hasil maupun proses pembelajaran. oleh karena itu, dalam penggunaan media pembelajaran harus memperhatikan rambu-rambu mekanisme media pembelajaran.

f. Mengurangi terjadinya verbalisme. Dalam pembelajaran sering terjadi siswa mengalami verbalisme karena apa yang diterangkan atau dijelaskan guru lebih bersifat abstrak atau tidak ada wujud, tidak ada ilustrasi nyata atau salah contoh, sehingga siswa hanya bisa mengatakan tetapi tidak memahami bentuk, wujud dan karakteristik objek. Dengan demikian media pembelajaran dapat berfungsi sebagai alat yang efektif dalam memperjelas pesan yang disampaikan.

g. Mengatasi keterbatasan ruang, waktu, tenaga, dan daya indera. Sering terjadi dalam pembelajaran menjelaskan objek pembelajaran yang sifatnya sangat luas, besar, atau sempit, kecil atau bahaya, sehingga memerlukan alat bantu untuk menjelaskan, mendekatkan pada objek yang dimaksud.

Fungsi media di dalam proses pembelajaran cukup penting dalam meningkatkan kualitas proses pembelajaran terutama membantu siswa untuk belajar. Sedangkan menurut Hamalik dlaam Rusman (2012 : 164) fungsi media pembelajaran yaitu :

a. Untuk mewujudkan situasi pembelajaran efektif

b. Penggunaan media merupakan bagian integral dalam sistem pembelajaran

c. Penggunaan media dalam pembelajaran adalah untuk mempercepat proses pembelajaran dan membantu siswa dalam upaya memahami materi yang disajikan oleh guru dalam kelas

d. Media pembelajaran penting dalam rangka mencapai tujuan pembelajaran

e. Penggunaan media dalam pembelajaran dimaksudkan untuk mempertinggi mutu pendidikan.

Pemerolehan pengatahuan, perubahan sikap dan keterampilan, dapat terjadi karena interaksi antara pengalalaman baru dengan pengalaman yang pernah dialami sebelumnya. Menurut Bruner (Rusman ;2012 ;165) ada tingkatan utama modus belajar yaitu penagalaman langsung, pengalaman gambar, pengalaman abstrak. Materi yang ingin disampaikan dan diinginkan siswa dapat menguasainya disebut sebagai pesan. Proses pembelajaran dapat berhasil dengan baik apabila siswa diajak untuk memanfaatkan semua alat inderanya. Guru berupaya untuk menampilkan rangsangan yang dapat diproses dengan berbagai inderanya. Semakin banyak alat indera yang digunakan untuk menerima dan mengolah informasi semakin besar kemungkinan informasi tersebut dimengerti dan dipahami serta dapat dipertahankan dalam ingatan. 
Perbandingan perolehan hasil belajar melalui indera pendang dan indera dengar sangat ,menonjol perbedaannya. Kurang lebih $80 \%$ hasil belajar seseorang diperolah melalui alat pandang, dan hanya $15 \%$ diperoleh melalui alat dengar, dan 5\% lagi dari indera yang lainnya. Untuk lebih jelasnya dapat dilihat pada gambar cone experience dari Dale berikut :

Dasar pengembangan kerucut di atas bukanlah tingkat kesulitan, melainkan tingkat keabstrakan jumlah jenis indera yang turut serta selama penerimaan si pembelajaran. pengalam langsung akan memberikan kesan paling utuh dan paling bermakna mengenai informasi dan gagasan yang terkandung dalam pengalaman itu. Oleh karena itu, ia melibatkan indera penglihatan, pendengaran, perasaan, penciuman, dan peraba. Ini dikenal dengan learning by doing atau learning to do.

Menurut Gerlac dan Ely (Rusman ; 2012 : 166) ada tiga cirri media yang merupakan petunjuk mengapa media digunakan dan apa saja yang dapat dilakukan oleh media yang mungkin guru tidak mampu melakukannya :

a. Ciri Fiksatif. Ciri ini menggambarkan kemampuan media merekam, menyimpan, melestarikan, dan erekomendasikan, merekonstruksi suatu peristiwa atau objek. Cirri ini amat penting bagi guru karena kejadian atau objek yang telah direkam dengan format media yang ada dapat digunakan setiap saat bahkan dapat ditransfer ke dalam format lainnya. Peristiwa kejadiannya hanya sekali dapat diabadikan dan disusun kembali untuk keperluan kegiatan pembelajaran.

b. Ciri Manipulatif. Transformasi suatu kejadian atau objek dimungkinkan karena media memiliki ciri manipulatif. Kejadian yang memakan waktu lama dapat disajikan kepada siswa dalam waktu sekejap dengan teknik pengambilan gambar. Kemampuan media dari ciri manipulatif ini memerlukan perhatian lebih karena apabila terjadi kesalahan apabila terjadi kesalahan dalam pengaturan kembali urutan kejadian atau pemotongan bagian yang salah, maka akan terjadi pula kesalahan penafsiran, sehingga dapat merubah sikap siswa kea rah yang tidak diinginkan.

c. Ciri Distributif. Ciri ini memungkinkan suatu objek atau kejadian ditransportasikan melalui ruang dan secara bersamaan kejadian tersebut disajikan kepada sejumlah besar siswa dengan stimulus pengelaman yang relative sama mengenai kejadian.

Menurut Rusman (2012: 168) ada beberapa tahap yang harus diperhatikan dalam pemilihan media pembelajaran, di antaranya :

a. Menetukan media pembelajaran berdasarkan identifikasi tujuan pembelajaran atau kompetensi dan karakteristik aspek amteri pelajaran yang akan dipelajari.

b. Mengidentifikasi kkarakteristik media pembelajaran harus disesuaikan dengan tingkat kemampuan siswa, penggunaannya dikuasi oleh guru, ada di sekolah, mudah penggunaannya, tidak memerlukan waktu yang banyak atau sesuai dengan waktu yang disediakan, dapat mencapai tujuan pembelajaran dan meningkatkan kreativitas ssiwa.

c. Mendesain penggunaannya dalam proses pembelajaran bagaimana tahapan penggunaannya sehingga menjadi proses yang utuh dalam proses pembelajaran

d. Mengevaluasi penggunaan media pembelajaran sebagai bahan umpan balik dari efektivitas dan efisiensi media pembelajaran,

Kegiatan pembelajaran berbasiskan teknologi komputer akan mengubah tuntutan peranan guru dalam pembelajaran. Guru tidak lagi bertindak sebagai penyampai materi, tetapi lebih bertindak sebagai fasilitator bagi siswa untuk menemukan konsep-konsep yang dipelajari, tentu saja dalam proses menemukan ini adalah proses menemukan kembali konsep yang telah ditemukan. Animasi yang efektif memerlukan kepatuhan untuk beberapa aturan atau prinsip-prinsip mendasar yang dikembangkan antara lain :

a. Prinsip pertama adalah bahwa animasi harus dinarasikan secara lisan, sebaiknya dengan nada percakapan (Mayer dan Anderson, 1992; Sweller, 1994; Lowe, 2003; Mayer, 2003).

b. Prinsip kedua adalah bahwa kotak teks atau label harus muncul dari struktur yang tepat seperti yang pertama kali disebutkan dan bahwa nilai dari label ini ditingkatkan dengan mendengar teks pada waktu yang sama (Mayer, 2003).

c. Prinsip ketiga adalah bahwa materi harus tidak terlalu detail, dan tidak berlebihan (Tversky dan Morrison, 2002).

d. Prinsip keempat adalah bahwa elemen kontrol (misalnya, kemampuan untuk 
berhenti, mundur, cepat-maju) harus disediakan (Tversky dan Morrison, 2002).

Sumber (www. komunitasbiologi.com)

O’day dalam penelitiannya yang berjudul "Animated Cell Biology: A Quick and Easy Method for Making Effective, High-Quality Teaching Animations" menjelaskan bahwa animasi bernarasi lebih efektif daripada animasi tanpa narasi untuk menghadirkan pembelajaran yang berkualitas (www. komunitasbiologi.com).

Microsoft mengembangkan salah satu program (software) yang dapat digunakan sebagai perangkat untuk mempresentasikan materi kepada audiens, termasuk di dalam proses pembelajaran di sekolah, yakni Microsoft Power Point. Program ini selain untuk presentasi, juga menyediakan berbagai fasilitas untuk berkreasi, mengolah, dan mengimput file audio maupun visual. Keterbatasannya di dalam berkreasi dan mengolah audio-visual dapat diselesaikan dengan mengintegrasikan dengan programprogram lain. Hasil kreasi dan olahan dari program lain kemudian diinput ke dalam program ini untuk diolah dan dipresentasikan. (http://sukarman blogspot.com).

Dengan kata lain gaya belajar adalah cara seseorang dalam menerima hasil belajar dengan tingkat penerimaan yang optimal dibandingkan dengan cara yang lain. Setiap orang memiliki gaya belajar masing-masing. Pengenalan gaya belajar sangat penting. Bagi guru dengan mengetahui gaya belajar tiap siswa maka guru dapat menerapkan tekhnik dan strategi yang tepat baik dalam pembelajaran maupun dalam pengembangan diri. Hanya dengan penerapan yang sesuai maka tingkat keberhasilannya lebih tinggi. Seorang siswa juga harus memahami jenis gaya belajarnya. Dengan demikian, ia telah memiliki kemampuan mengenal diri yang lebih baik dan mengetahui kebutuhannya. Pengenalan gaya belajar akan memberikan pelayanan yang tepat terhadap apa dan bagaimana sebaiknya disediakan dan dilakukan agar pembelajaran dapat berlangsung optimal. Secara realita jenis gaya belajar seseorang merupakan kombinasi dari beberapa gaya belajar. Selain itu, gaya belajar adalah cara yang lebih disukai dalam melakukan kegiatan berfikir, memproses, dan mengerti suatu informasi. Gaya belajar merupakan gaya seorang dalam mengolah dan menyerap informasi atau mempelajari sesuatu dari pengalamannya sehingga ia dengan mudah menerima informasi yang diterimanya baik melalui pendengaran, penglihatan maupun melakukannya, yang akhirnya dapat memahami informasi yang didapatnya. Hasil riset menunjukkan bahwa siswa yang belajar dengan menggunakan gaya belajar mereka yang dominan, saat mengerjakan tes akan mencapai hasil yang lebih baik dibandingkan apabila mereka belajar dengan cara yang tidak sejalan dengan gaya belajar mereka.

Gaya belajar dapat digunakan untuk membantu memaksimalkan proses pembelajaran, karena: (1) mengerti gaya belajar siswa, sehingga tidak terpaku pada satu gaya belajar saja, (2) mengakomodasikan gaya belajar yang berbeda, tetapi tidak mencoba untuk memaksakan semua pada saat proses pembelajaran, (3) mulai menyadari bahwa gaya belajar juga merupakan faktor yang perlu diperhatikan.

Perbedaan gaya belajar tidak menggmabarkan perbedaan dalam tahap kecerdasan. Gaya belajar merujuk pada strategi dan teknik yang disukai dan yang digunakan oleh individu ketika belajar. Hal ini melibatkan kecendrungan individu mengamati dan memproses informasi, bukan kemahiran dalam belajar. Pelajar yang mempunyai gaya belajar yang berbeda akan mendapat pencapaian yang mungkin berbeda walaupun situasinya sama. Gaya belajar indikator bertindak yang relatif stabil untuk pembelajar yang saling berhubungan dan bereaksi terhadap lingkungan belajar. Anggapan umum bahwa gaya belajar seseorang berasal dari variabel kepribadian, termasuk susnan kognitif dan psikologis latar belakang sosiokultural, dan pengalaman pendidikan.

Secara teoritis, argumen tentang pentingnya memahami gaya belajar peserta didik utnuk mencapai hasil belajar yang optimal sudah menjadi simpulan utama. Masing-masing individu, termasuk peserta didik, memiliki gaya belajar berbeda. Individu dengan IQ yang sama, kecakapan yang sama, dan kemampuan memproses informasi yang sama, dalam banyak hal akan berbeda dari cara mereka menerima sesuatu, cara berfikir, menyelesaikan berbagaii persoalan, dan mengingat sesuatu.

Hasil belajar optimal akan diperoleh apabila beragam perbedaan seperti kebiasaan, minat, dan gaya belajar pada peserta didik diakomodasikan oleh guru melalui pemilihan metode mengajar dan materi ajar yang sesuai dengan gaya belajar peserta didik. Penagajaran 
bidang studi apapun, hanya bisa ditingkatkan kualitasnya, apabila guru memahami karakteristik peserta didik dengan baik termasuk gaya belajar mereka. Kemudian, informasi tentang peserta didik tersebut menjadi bahan pertimbangan bagi guru dalam memilih metode, media, teknik mengajar, dan materi ajar yang sesuai dengan keberagaman gaya belajar peserta didik.

Masalah penelitian ini dapat dirumuskan sebagai berikut: (1) Apakah hasil belajar biologi siswa yang diajar dengan media pembelajaran animasi lebih tinggi daripada siswa yang diajar dengan media pembelajaran powerpoint ?; (2) Apakah hasil belajar biologi siswa yang memiliki gaya belajar visual lebih tinggi daripada siswa yang memiliki gaya belajar auditori?; dan (3) Apakah terdapat interaksi antara media pembelajaran dengan gaya belajar terhadap hasil belajar biologi siswa?

\section{METODE}

Penelitian dilaksanakan di SMA Swasta Persiapan Stabat jln. Perniagaan No. 31 A. Penelitian ini dilaksanakan sebanyak delapan kali pertemuan yang berlangsung pada bulan Oktober 2013. Penetapan waktu penelitian disesuaikan dengan kalender akademik dan jadwal mata pelajaran Biologi di sekolah tersebut. Populasi adalah totalitas semua nilai yang mungkin, hasil menghitung ataupun pengukuran, kuantitatif maupun kualitatif mengenai karakteristik tertentu dari semua anggota kumpulan yang lengkap dan jelas yang ingin dipelajari sifat-sifatnya. Maka yang menjadi populasi penelitian ini adalah siswa SMA Swasta Persiapan Stabat kelas XI yang berjumlah 107 orang. Masing-masing kelas IPA 1 dengan jumlah siswa 39 orang, Kelas XI IPA 2 dengan jumlah siswa 38 orang dan IPA 3 dengan jumlah siswa 30 orang.

Penarikan sampel dilakukan secara acak yakni dari 3 kelas diperoleh 2 kelas eksperimen. Dasar penarikan sampel pada ketiga kelas ini didasarkan pada asumsi kesamaan pada tingkat kelas tanpa adanya kelas unggulan, usia rata-rata siswa, tidak ada siswa yang memiliki usaha sampingan secara mandiri, serta kurikulum dan fasilitas pembelajaran yang sama. Teknik pengambilan sampel dilakukan dengan teknik cluster random sampling, dari dua kelas yang terpilih sebagai sampel penelitian maka kelas XI IPA 1 terpilih sebagai kelas yang diberi perlakuan dengan media pembelajaran Animasi dan kelas XI IPA 2 terpilih sebagai kelas yang diberi perlakuan dengan media pembelajaran Powerpoint. Sebelum dilakukan eksperimen, kedua kelas sampel terlebih dahulu diberi tes dalam bentuk angket untuk mengetahui gaya belajar siswa.

Penelitian ini menggunakan metode quasy experiment (eksperimen semu). Hal ini dimaksudkan karena di dalam eksperimen, kelas ini sudah terbentuk sebelumnya. Rancangan penelitian menggunakan desain faktorial $2 \times 2$ seperti digambarkan pada tabel 1 . berikut :

Tabel 1. Desain Penelitian Faktorial 2x2

\begin{tabular}{|c|c|c|}
\hline $\begin{array}{c}\text { Media Pembelajaran (B) } \\
\text { Gaya Belajar (A) }\end{array}$ & Animasi & Powerpoint \\
\hline Visual & $\mathrm{A}_{1} \mathrm{~b}_{1}$ & $\mathrm{~A}_{2} \mathrm{~B}_{1}$ \\
\hline Auditori & $\mathrm{A}_{1} \mathrm{~b}_{2}$ & $\mathrm{~A}_{2} \mathrm{~b}_{2}$ \\
\hline
\end{tabular}

\section{Keterangan :}

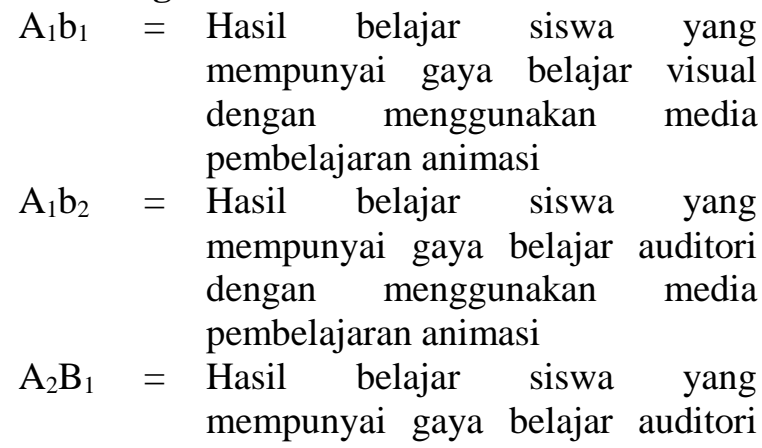

$\mathrm{A}_{2} \mathrm{~b}_{2}=$ Hasil belajar siswa yang mempunyai gaya belajar auditori dengan menggunakan media pembelajaran powerpoint

Teknik analisis data yang dipergunakan dalam penelitian ini adalah Teknik Statistik Deskriptif dan Inferensial. Teknik statistik deskriptif digunakan untuk mendeskripsikan data, antara lain: nilai rata-rata (mean), median, standart deviasi (Sd) dan kecenderungan data. 
Teknik statistik inferensial digunakan untuk menguji hipotesis penelitian, dimana teknik inferensial yang akan digunakan adalah teknik analisis varians Anava dua jalur (desain faktorial $2 \times 2$ ) dengan taraf signifikan 0,05 . sebelum Anava dua jalur dilakukan, terlebih dahulu dilakukan uji persyaratan analisis yakni uji persyaratan Normalitas dan Homogenitas. Untuk uji persyaratan Normalitas menggunakan uji Liliefors, sedangkan untuk uji persyaratan Homogenitas varians menggunakan Uji Bartlett. adalah :

Adapun hipotesis yang akan diuji

Hipotesis $1 \quad$ : Ho $: \mu_{A 1}=\mu_{A 2}$

$$
\mathrm{H} 1: \mu_{A 1}>\mu_{A 2}
$$

Hipotesis $2 \quad$ : $\quad$ Ho $: \mu_{B 1}=\mu_{B 2}$

$\mathrm{H} 1: \mu_{B 1}>\mu_{B 2}$

Hipotesis 3 : Ho : $\mathrm{A} \times \mathrm{B}=0$

$\mathrm{H} 1: \mathrm{A} \times \mathrm{B} \neq 0$

\section{HASIL DAN PEMBAHASAN}

Hasil

Untuk keperluan pengujian hipotesis dengan menggunakan teknik analisis varian dua jalur (ANAVA) faktorial $2 \times 2$ dan uji lanjut Scheffe diperlukan harga rata-rata tiap kelompok, berikut ini disajikan data hasil belajar biologi siswa pada Tabel 2 dengan menggunakan analisis deskriptif.

Tabel 2. Rangkuman Data Hasil Perhitungan Analisis Deskriptif

\begin{tabular}{|c|c|c|c|c|}
\hline \multirow{2}{*}{\multicolumn{2}{|c|}{ Ringkasan Data }} & \multicolumn{2}{|c|}{ Media Pembelajaran } & \multirow[t]{2}{*}{ Total } \\
\hline & & Animasi (A) & Powerpoint $(\mathrm{P})$ & \\
\hline \multirow{2}{*}{$\begin{array}{l}\text { Gaya } \\
\text { Belajar }\end{array}$} & $\begin{array}{l}\text { Visual } \\
(\mathrm{Gv})\end{array}$ & $\begin{array}{l}\mathrm{N}_{1}=10 \\
\sum P_{1}=259 \\
\sum_{\bar{X}} X^{2}{ }_{1}=6755 \\
S^{2}{ }_{1}=3,73\end{array}$ & $\begin{array}{l}N_{3}=11 \\
\sum P_{3}=250 \\
\sum_{\bar{X}_{3}=22,86} X^{2}{ }_{3}=5752 \\
S^{2}{ }_{3}=6,26\end{array}$ & $\begin{array}{l}\sum_{1,3}^{\mathrm{N}_{1,3}}=21 \\
\sum_{\bar{X}} \mathrm{P}_{1,3}=509 \\
\mathrm{X}_{1,3}^{2}=12507 \\
\mathrm{~S}_{1,3}^{2}=24,24 \\
=6,90\end{array}$ \\
\hline & $\begin{array}{l}\text { Auditori } \\
\text { (Ga) }\end{array}$ & $\begin{array}{l}\sum_{2}^{\mathrm{N}_{2}}=10 \\
\sum_{\bar{X}_{2}} \mathrm{X}^{2}{ }_{2}=4292 \\
\bar{X}_{2}=20,60 \\
\mathrm{~S}_{2}{ }_{2}=3,96\end{array}$ & $\begin{array}{l}\sum_{4}^{\mathrm{N}_{4}=11} \mathrm{P}_{4}=234 \\
\sum_{\bar{X}_{4}=21,27} \mathrm{X}^{2}{ }_{4}=5024 \\
\mathrm{~S}_{4}{ }_{4}=4,30\end{array}$ & $\begin{array}{l}\sum_{2,4}^{\mathrm{N}_{2,4}}=21 \\
\sum_{2,4}=440 \\
\bar{X}_{2,4} \mathrm{X}_{2,4}=9316 \\
\mathrm{~S}_{2,4}=4,25\end{array}$ \\
\hline \multicolumn{2}{|l|}{ Total } & $\begin{array}{l}\sum_{1,2}=20 \\
\sum_{\bar{X}_{1,2}=23,25} \mathrm{P}_{1,2}=465 \\
\mathrm{~S}_{1,2}^{2}=11047 \\
\mathrm{~N}_{1,82}\end{array}$ & $\begin{array}{l}\sum_{3,4}=22 \\
\sum_{\bar{X}_{3,4}=21,18} \mathrm{X}_{3,4}^{2}=48776 \\
\mathrm{~S}_{3,4}^{2}=5,66\end{array}$ & 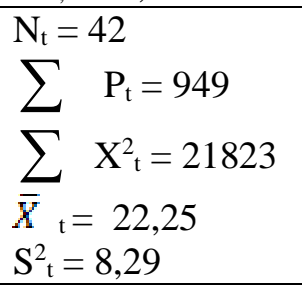 \\
\hline
\end{tabular}

Setelah data Tabel 2 diolah dengan ANAVA 2 jalur faktorial $2 \times 2$, maka diperoleh hasil analisis seperti ditunjukkan pada Tabel 3

Tabel 3. Ringkasan Perhitungan ANAVA Faktorial 2 x 2

\begin{tabular}{|c|c|c|c|c|c|c|}
\hline Sumber Varians & JK & Dk & KT & $\mathrm{F}_{\text {hitung }}$ & $\begin{array}{l}\mathrm{F}_{\text {tabel }} \\
(\alpha=0,05)\end{array}$ & Keterangan \\
\hline Media & 25,76 & 1 & 25,76 & 4,59 & \multirow{3}{*}{4,10} & Signifikan \\
\hline Gaya Belajar & 113,36 & 1 & 113,36 & 20,35 & & Signifikan \\
\hline Interaksi & 29,28 & 1 & 29,28 & 5,26 & & Signifikan \\
\hline Dalam Kelompok (galat) & 211,7 & 38 & 5,57 & & & \\
\hline Total & 380,1 & & & & & \\
\hline
\end{tabular}


Data yang diperoleh dalam penelitian ini berasal dari sampel yang jumlahnya berebda untuk setiap sel ANAVA. Sehingga perlu dilakukan uji Scheffee, hasil pengujian dengan menggunakan uji scheffee dapat dilihat dalam Tabel 4.

Tabel 4. Ringkasan Hasil Pengujian Dengan Menggunakan Uji Scheffee

\begin{tabular}{|c|c|c|c|c|c|}
\hline No & \multicolumn{2}{|c|}{ Hipotesis Statistik } & $\mathrm{F}_{\text {hitung }}$ & \multicolumn{2}{c|}{$\mathrm{F}_{\text {tabel }}$} \\
\cline { 4 - 5 } & & & $\alpha=5 \%$ & $\alpha=1 \%$ \\
\hline 1 & $\mathrm{H}_{0}: \mu_{1}=\mu_{2}$ & $\mathrm{Ha}: \mu_{1}>\mu_{2}$ & 1,92 & 2,85 & 4,34 \\
\hline 2 & $\mathrm{H}_{0}: \mu_{1=} \mu_{3}$ & $\mathrm{Ha}: \mu_{1}>\mu_{3}$ & 3,20 & 2,85 & 4,34 \\
\hline 3 & $\mathrm{H}_{0}: \mu_{1}=\mu_{4}$ & $\mathrm{Ha}: \mu_{1}>\mu_{4}$ & 2,93 & 2,85 & 4,34 \\
\hline 4 & $\mathrm{H}_{0}: \mu_{2=} \mu_{3}$ & $\mathrm{Ha}: \mu_{2}>\mu_{3}$ & 4,29 & 2,85 & 4,34 \\
\hline 5 & $\mathrm{H}_{0}: \mu_{2}=\mu_{4}$ & $\mathrm{Ha}: \mu_{2}>\mu_{4}$ & 1,05 & 2,85 & 4,34 \\
\hline
\end{tabular}

\section{Pembahasan}

Dari hasil pengolahan data yang dilakukan terdapat perbedaan hasil belajar biologi antara siswa yang diajar dengan media pembelajaran animasi dengan media pembelajaran powerpoint, yaitu rata-rata hasil belajar biologi siswa yang diajar dengan media pembelajaran animasi lebih tinggi daripada rata-rata hasil belajar biologi siswa yang diajar dengan media pembelajaran powerpoint. Kenyataan ini membuktikan bahwa media pembelajaran aniamsi lebih baik dalam meningkatkan pemahaman siswa dalam pembelajaran biologi daripada penggunaan media pembelajaran powerpoint. Dengan demikian mengajarkan materi biologi akan lebih baik menggunakan media pembelajaran animasi dibanding media pembelajaran powerpoint.

Dengan menggunakan media animasi yang merupakan jenis media dimana terjadinya pergerakan dalam materi sehingga memudahkan siswa dalam memahami isi materi, dengan kata lain animasi memiliki kemampuan untuk dapat memaparkan sesuatu yang rumit untuk dijelaskan hanya dengan gambar atau kata-kata saja. Dengan kemampuan ini maka animasi dapat digunakan untuk menjelaskan suatu materi yang secara nyata tidak dapat terlihat oleh mata, dengan cara melakukan visualisasi maka materi yang dijelaskan dapat tergambarkan. Selain itu animasi sebagai media ilmu pengetahuan dapat dijadikan sebagai perangkat ajar yang siap kapan saja untuk mengajarkan materi yang telah dianimasikan keadaan seperti ini merupakan kondisi yang optimal bagi siswa untuk menerima informasi. Sedangkan media powerpoint merupakan media yang tidak terdapat pergerakan dalam menyampaikan materi pelajaran.
Meski dalam penelitian ini diperoleh data bahwa hasil belajar biologi siswa lebih tinggi jika diajar dengan media pembelajaran aniamsi daripada media pembelajaran powerpoint , namun dalam pelaksanaannya kedua media ini secara umum telah mampu meningkatkan ratarata hasil belajar biologi siswa. Ini terbukti dari perolehan rata-rata hasil belajar pada kedua kelas perlakuan terjadi peningkatan setelah perlakuan dilaksanakan jika dibandingkan sebelum perlakuan dilaksanakan. Ini membuktikan bahwa pemeblajaran dengan media lebih baik jika dibandingkan dengan pembelajaran tanpa menggunakan media pembelajaran. Berdasarkan hasil penelitian Emelda Marzuki mengenai Pengaruh Animasi Multimedia dengan Model Pembelajaran Kooperatif Tipe STAD Terhadap Penguasaan Materi Biologi Siswa menjelaskan bahwa penggunaan animasi multimedia dengan model pembelajaran kooperatif tipe STAD memberikan pengaruh yang signifikan terhadap penguasaan materi pokok Sistem Peredaran Darah oleh siswa dan penguasaan materi pokok Sistem Peredaran Darah oleh siswa pada penggunaan animasi multimedia dengan model pembelajaran kooperatif tipe STAD lebih tinggi dibanding tanpa menggunakan animasi multimedia.

Hasil penelitian menunjukkan bahwa rata-rata hasil belajar biologi siswa yang memiliki gaya belajar visual lebih tinggi daripada hasil belajar biologi siswa yang memiliki gaya belajar auditori. Selanjutnya dalam penelitian ini juga terbukti bahwa hasil belajar biologi siswa yang memiliki gaya belajar visual lebih tinggi daripada hasil belajar biologi siswa yang diajar dengan media powerpoint. Hal ini mengindikasikan bahwa siswa yang mempunyai gaya belajar visual lebih mampu memahami bahan pelajaran 
biologi dibanding siswa yang memiliki gaya belajar auditori. Penelitian ini juga membuktikan bahwa siswa yang memiliki gaya belajar visual lebih cocok diajar dengan menggunakan media pembelajaran animasi. Pembelajaran dengan menggunakan animasi sangat tepat dibandingkan media pembelajaran powerpoint pada siswa yang memiliki gaya belajar visual.

Siswa yang memiliki gaya belajar visual modalitas ini menyerap citra terkait dengan visual, warna, gambar, peta, diagram. Model pembelajar visual menyerap informasi dan belajar dari apa yang dilihat oleh mata. Beberapa ciri dari pembelajar visual di antaranya adalah: 1. Mengingat apa yang dilihat, daripada yang didengar. 2. Suka mencoret-coret sesuatu, yang terkadang tanpa ada artinya saat di dalam kelas 3. Pembaca cepat dan tekun 4. Lebih suka membaca daripada dibacakan 5. Rapi dan teratur 6 . Mementingkan penampilan, dalam hal pakaian ataupun penampilan keseluruhan 7. Teliti terhadap detail 8. Pengeja yang baik, 9. Lebih memahami gambar dan bagan daripada instruksi tertulis. Sebaliknya siswa yang memiliki gaya belajar model pembelajar auditori adalah model di mana seseorang lebih cepat menyerap informasi melalui apa yang ia dengarkan. Penjelasan tertulis akan lebih mudah ditangkap oleh para pembelajar auditori ini. Ciri-ciri orang-orang auditorial, di antaranya adalah: (1) Lebih cepat menyerap dengan mendengarkan (2) Menggerakkan bibir mereka dan mengucapkan tulisan di buku ketika membaca, (3) Senang membaca dengan keras dan mendengarkan (4) Dapat mengulangi kembali dan menirukan nada, birama, dan warna suara. (5) Bagus dalam berbicara dan bercerita (6) Berbicara dengan irama yang terpola; (7) Belajar dengan mendengarkan dan mengingat apa yang didiskusikan daripada yang dilihat (8) Suka berbicara, suka berdiskusi, dan menjelaskan sesuatu panjang lebar (9) Lebih pandai mengeja dengan keras daripada menuliskannya (10) Suka musik dan bernyanyi (11) Tidak bisa diam dalam waktu lama (12) Suka mengerjakan tugas kelompok.

Temuan penelitian menunjukkan bahwa ada interaksi antara media pembelajaran dan gaya belajar. Siswa yang memiliki gaya belajar visual yang diajar dengan media pembelajaran animasi lebih tinggi hasil belajar biologinya daripada siswa yang memiliki gaya belajar auditori yang diajar dengan media pembelajaran animasi. Demikian pula siswa yang memiliki gaya belajar auditori yang diajar dengan media pembelajaran powerpoint memperoleh hasil belajar biologi lebih tinggi daripada siswa yang memiliki gaya belajar visual dengan media pembelajaran powerpoint. Hal ini mengindikasikan adanya interaksi antara media pembelajaran dengan gaya belajar terhadap hasil belajar biologi siswa.

Media animasi yang merupakan kumpulan gambar yang diolah sedemikian rupa sehingga menghasilkan gerakan dan dilengkapi dengan audio sehingga berkesan hidup serta menyimpan pesan-pesan pembelajaran. Kehadiran media animasi dalam pembelajaran Biologi sangat mendukung proses penyampaian berbagai informasi dari guru ke siswa. Prosesproses biologi yang kompleks dapat dengan mudah dijelaskan kepada siswa, seperti proses fotosintesis, respirasi aerob, dan berbagai proses dalam sistem organ manusia. Pada proses belajar mengajar, siswa sering dihadapkan pada materi yang abstrak dan diluar pengalaman sehari-hari sehingga matri pelajaran sulit diterima dan dipahami oleh siswa. Keistimewaan yang dimiliki oleh animasi intinya untuk memvisualisasikan konsep abstrak yang sulit dipraktekkan dikelas. Dengan jalan ini siswa yang memiliki gaya belajar visual akan lebih terpacu dalam menemukan ide-ide dan gagasan serta lebih mudah menyerap informasi pengetahuan yang diberikan. Sementara itu pada siswa yang memiliki gaya belajar auditori siswa yang memiliki gaya belajar auditori, cenderung mereka mulai belajar dengan baik terutama dengan mendengarkan dan dengan mudah mengingat informasi kompleks yang didengar. Anak yang mempunyai gaya belajar auditori dapat belajar lebih cepat dengan menggunakan diskusi verbal dan mendengarkan apa yang guru katakan. Dengan media powerpoint yang hanya menampilkan kalimat-kalimat pokok yang terdapat di slide dan guru yang menjabarkan lebih kompleks materi yang diberikan sangat cocok untuk tipe anak yang memiliki gaya belajar auditori. Siswa yang memiliki gaya belajar auditori jika diajar dengan menggunakan media animasi mereka akan kurang terfokus sebab siswa yang memiliki gaya belajar auditori lebih suka mendengarkan apa yang dikatakan oleh guru, mereka lebih mengandalkan alat pendengaran daripada alat penglihatan.

Dengan media powerpoint yang hanya 
menampilkan kalimat-kalimat pokok yang terdapat di slide dan guru yang menjabarkan lebih kompleks materi yang diberikan sangat cocok untuk tipe anak yang memiliki gaya belajar auditori. Siswa yang memiliki gaya belajar auditori jika diajar dengan menggunakan media animasi mereka akan kurang terfokus sebab siswa yang memiliki gaya belajar auditori lebih suka mendengarkan apa yang dikatakan oleh guru, mereka lebih mengandalkan alat pendengaran daripada alat penglihatan. Jika dikaitkan dengan hasil belajar biologi maka penerapan media powerpoint dengan gaya belajar auditori akan meningkatkan hasil belajarnya, dan begitu juga sebaliknya siswa yang mempunyai gaya belajar visual akan meningkat hasil belajarnya jika menerapkan multimedia animasi dalam pembelajaran.

\section{PENUTUP \\ Simpulan}

Berdasarkan hasil penelitian dan

pembahasan yang dikemukakan sebelumya, maka dapat disimpulkan bahwa :

1. Hasil belajar biologi siswa yang diajarkan dengan media pembelajaran animasi lebih tinggi dibandingkan dengan hasil belajar biologi siswa yang diajarkan dengan media pembelajaran powerpoint

2. Hasil belajar biologi siswa yang memiliki gaya belajar visual lebih tinggi daripada siswa yang memiliki gaya belajar auditori

3. Terdapat interaksi antara media pembelajaran dan gaya belajar siswa terhadap hasil belajar biologi. Dari hasil pengujian lanjut ternyata hasil belajar biologi siswa yang memiliki gaya belajar visual lebih tinggi jika diajar dengan menggunakan media pembelajara animasi sedangkan siswa yang memiliki gaya belajar auditori emperoleh hasil belajar biologi lebih tinggi jika diajarkan dengan menggunakan media pembelajaran powerpoint.

\section{Saran}

Berdasarkan simpulan dan implikasi seperti yang telah dikemukakan, maka disarankan beberapa hal berikut :

Disarankan bagi guru untuk menggunakan media pembelajaran, agar hasil belajar biologi siswa tersebut lebih tinggi, karena pembelajaran menggunakan media sangat sesuai dengan pembelajaran biologi.
Untuk meningkatkan hasil belajar biologi siswa yang memiliki gaya belajar visual, media pembelajaran animasi sebagai salah satu alternatif yang sesuai dengan karakter siswa tersebut, di samping itu dengan media pembelajaran ini siswa akan lebih terlatih dan terbiasa bekerja sama untuk menyelesaikan permasalahannya, demikian juga disarankan bagi guru untuk menggunakan media pembelajaran powerpoint untuk membelajarkan siswa yang memiliki gaya belajar auditori agar hasil belajarnya lebih tinggi.

Penggunaan media pembelajaran yang sesuai dengan karakteristik siswa dan materi pembelajaran memberi pengaruh pada hasil belajar siswa. Oleh sebab itu disarankan bagi kepala sekolah untuk melatih guru-guru dalam menggunakan media khususnya IT (Instructional Technology) dan meningkatkan pengawasan pelaksanaan pembelajaran siswa di kelas.

\section{DAFTAR PUSTAKA}

AECT. 1986. Defenisi Teknologi Pendidikan. Jakarta: PAU-UT dan Rajawali

Ahmadi, A. (2003). Psikologi Umum. Jakarta : Rineka Cipta

Ahnadi, Rike. (2009). Skripsi (Efektifitas Media Sofware Autograph Menggunakan Model Pembelajaran Kooperatif Tipe ThinkPair-Share Pada Pembelajaran Persamaan Garis Lurus di Kelas VIII SMP N 1 Tanjung pura T.A. 2008-2009. Medan : FMIPA Unimed

Anderson, O.W. dan Krathwohl, D.R. 2001. A Taxonomy for Learning Teaching and Assesning. New York: Addison Wesley Longman

Ariani, Niken. Dany Haryanto. (2010). Pembelajaran Multimedia di Sekolah. Jakarta : PT. Prestasi Pustakarya

Arsyad, Azhar. (2002). Media Pembelajaran. Jakarta : Rajagrafindo Persada

Budiningsih, Asri. (2004). Belajar dan Pembelajaran. Jakarta : Rineka Cipta

Cahyo, Nur. A. (2008). Pengembangan Model Creative Problem Solving Berbasis Teknologi. Tersedia di ; http://adinegara.blogspot.com

Covey, S.R. (1994). Tujuh Kebiasaan Manusia yang Sangat Efektif. Terjemahan : Budiyanto. Jakarta : Binarupa Aksara

Dahar, R.W. (1998). Teori-Teori Belajar. Bandung : Erlangga 
Daryanto, (2010). Belajar dan mengajar. Bandung : Yrama Widya

De Bono, E. (2007). Revolusi Bepikir. Bandung : Al Mizan

DePorter, B (2004). Quantum Learning, Bandung: Kaifa

Desmita. (2005). Psikologi Perkembangan. Bandung : Remaja Rosdakarya

Dick, W dan Carey, L. 2005. The Systematic Design of Instruction. Glenview, Illinois: Scoot, Foresman and Company

Dimyati dan Mudjiono. (1994). Belajar dan Pembelajaran. Jakarta : Direktorat Jenderal Perguruan Tinggi Depdikbud

Ermiyanti, (2007). Tesis (Penggunaan media pembelajaran dengan perangkat lunak bantu menggunakan sofware Macromedia Flash MX 2004 pada pokok bahasan trigonometri di kelas X SMA Negeri 19 Palembang)

Gagne, R.M (1985). The Conditions of Learning and Theory of Instruction (4 ${ }^{\text {th }}$ ed). Orlando : Holt, Rinehart, and Winston.

Hidayatulla, Priyanto. Dkk. (2010). Making Eduacational Animation using Flash. Jakarta : Informatika

Hamalik, O. (2001). Proses Belajar Mengajar. Jakarta: Bumi Aksara

Hamalik, O. 2008. Kurikulum dan Pembelajaran. Jakarta : Bumi Aksara.

Kunandar,(2007), Guru Profesionalisme Implementasi Kurikulum Tingkat Satuan Pendidikan (KTSP) dan Sukses dalam Sertifikasi Guru, Jakarta: Rajawali Pers

Marzuki, Emelda, (2009). (Pengaruh Animasi Multimedia dengan Model Pembelajaran Kooperatif Tipe STAD Terhadap Penguasaan Materi Biologi Siswa (studi Eksperimental pada siswa kelas XI SMA N 5 bandar lampung) Tesis

Mulyasa,E,(2003), Implementasi Kurikulum 2004 Panduan pembelajaran KBK, Jakarta:Rosda.
Nasution.(2008).Berbagai Pendekatan dalam Proses belajar Mengajar. Jakarta: Bumi Aksara

Puryaningsing, (2008). Penggunaan Media Animasi yang Ditinjau dari Motivasi Berprestasi dan Kemampuan Awal dalam pemebaljaran Biologi Umum (studi ekperimen pada mahasiswa semester 1 jurusan Pendidikan MIPA FKIP Universitas Palangkaraya. Tesis

Prawidilaga, Dewi Salma, (2008). Prinsip Desain Pembelajaran. Jakarta : Kencana

Prasnig, barbara, (2007), The Power of Learning Style, Bandung : Kaifa

Sagala,T. (2005). Konsep dan makna Pembelajaran, Bandung: alfabeta

Sanjaya, Wina. (2005). Pembelajaran dalam Implementasi Kurikulum Berbasis Kompetensi. Jakarta: Kencana.

Sanjaya, Wina. (2008). Perencanaan dan Desai Sistem Pembelajaran. Jakarta: Kencana.

Slameto,(2003), Belajar dan faktor-faktor yang Mempengaruhinya, Jakarta :Rineka Cipta.

Sudjana, N, (2005), Metoda Statistik. Bandung : PT. Tarsito

Sugiyono, (2009). Statistik Untuk Penelitian. Bandung: Alfabeta

Syafruddin,(2005), Model Pembelajaran yang Memperhatikan Keragaman Individu Siswa dalam Kurikulum berbasis Kompetensi, Ciputat: Quantum Teaching.

Syah, M,(2005), Psikologi Pendidikan dengan Pendekatan Baru, Bandung:Rosda.

Trianto,(2007), Model-model Pembelajaran Inovatif Berorientasi Kontruktivisme, Jakarta: Prestasi Pustaka Publisher.

Uno, Hamzah B. (2008). Orientasi Baru dalam Psikologi Pembelajaran. Jakarta : Bumi Aksara

Widodo, S. Chomsin, dkk, (2008). Panduan Menyusun Bahan Ajar. Jakarta : PT.Elex Media Komputindo 